Jolanta GORBACZ-PAZERA

\title{
SEGMENTACJA TEKSTU NAUKOWEGO
}

\section{Uwagi wstępne}

Struktura tekstu oznacza wewnętrzną budowę tekstu charakteryzującą się wielopoziomowością i wieloplanowością. Jej elementy są znaczące nie tylko same w sobie, lecz również w stosunku do całości. Spójność wewnętrznej budowy tekstu - koherencja ${ }^{1}$, jej względna samodzielność funkcjonowania oraz związek z rzeczywistością pozajęzykową, pozwalają rozpatrywać tekst jako swoisty „makroobraz”, zarówno $\mathrm{w}$ wypadku tekstu artystycznego, jak również w zakresie innych stylów funkcjonalnych, jako złożoną całość podlegającą wieloaspektowej analizie jej komponentów składowych.

Tekst przedstawia sobą pewien świat, który może w większym lub mniejszym stopniu pokrywać się z ogólnie akceptowanym wyobrażeniem świata rzeczywistego. Obraz świata tekstu niesie ze sobą więcej niż jeden sens zawarty w wyrażeniach językowych, ponieważ jego odbiór opiera się na konfrontacji wiedzy i doświadczeń oraz oczekiwań uczestników procesu komunikacji. Koherencja jest więc zarówno cechą tekstu, jak też rezultatem kognitywnych procesów użytkowników języka (por. R. A. Beaugrande, W. U. Dressler 1990: 199).

Konieczne w wypadku tekstu staje się rozgraniczenie pojęcia nie tylko wewnętrznej, lecz również i zewnętrznej struktury lub - w in-

1 Koherencja bazuje na ciągłości sensów przekazywanych przez tekst. Sens oznacza wiedzę przekazywaną poprzez wyrażenia językowe występujące w tekście. „Tekst ma sens, ponieważ istnieje ciągłość sensów w wiedzy zaktywizowanej przez wyrażenia tekstu. Bezsensowny lub nonsensowny tekst to taki, w którym odbiorcy nie mogą dostrzec żadnej ciągłości, zazwyczaj dlatego, że nie ma zgodności między konfiguracją pojęć i relacji wyrażonych $w$ tekście a uprzednią wiedzą odbiorcy o świecie" (R. A. Beaugrande, W. U. Dressler 1990: 199). 
nej terminologii - struktury głębokiej i powierzchniowej. Strukturą wewnętrzną nazywamy całokształt środków pełniących swoją rolę w granicach danego tekstu i biorących udział w jego strukturacji jako całości. Strukturę zewnętrzną reprezentuje całokształt środków służących do eksplikacji określonych treści w celu skonstruowania określonego makroobrazu, którego tworzywem są środki językowe - leksykalne, syntaktyczne i tekstowe.

Tekstolodzy zgodnie uważają, że obiektywnie uzasadniony podział tekstu jest konieczny zarówno w celu jego zbudowania, jak i uzmysłowienia go w charakterze strukturalno-semantyczno-komunikatywnej całości (por. T. Dobrzyńska 1974: 287-289; J. Grimes 1975: 108; W. Jr. Strunk i W. White 1979: 17; T. A. van Dijk 1980: 221, 1983: 188; de R. Beaugrande 1984: 316; J. Łotman 1984: 76; A. Duszak 1998: 127, 136).

W przypadku tekstów literackich, które zajmują szczególne miejsce w stylistycznym zróżnicowaniu języka (styl artystyczny), integracja i delimitacja oparte są na motywach o charakterze ekstralingwistycznym oraz indywidualno-psychologicznym (zob. E. Dąbrowska 1995: 219-362). Natomiast w tekstach stylów funkcjonalnych zarówno spójność (integrację), jak i segmentację (delimitację) ${ }^{2}$ dyktują stabilne zasady logiki rozumowania, co oznacza, że zarówno integracja, jak i delimitacja swoje podstawy wiążą ze skonwencjonalizowaną kompozycją prezentowanej treści. Fragmenty tekstowe powinny odzwierciedlać część informacji zgodnej z zamysłem autora odnośnie planu treści i adekwatnej do możliwości percepcyjnych odbiorcy, zapewniając logiczne następstwo tych części w danej całości, wyróżniające się przede wszystkim logicznym kontinuum. Autor dokonuje podziału przestrzeni tekstowej na akapity i ta odautorska delimitacja jest zgodna $z$ pragmatycznym ukierunkowaniem tekstu, jednakże często nie pokrywa się z po-

2 W badaniach nad problematyką delimitacji tekstu można wyodrębnić cztery stanowiska: 1) spójnościowe - kontynuujące badania V. Mathesiusa (1971), 2) poświęcone zbieraniu formuł początkowych i końcowych w różnych typach tekstów - głównie folklorystycznych, 3) stosujące kategorię metawypowiedzi oraz 4) charakteryzujące się podejściem semiotycznym (zob. T. Dobrzyńska 1974: 12-37). W naszej dysertacji przyjmujemy stanowisko spójnościowe i rozszerzamy je o aspekt funkcjonalno-komunikatywny. Terminy segmentacịa i delimitacja będą używane w odniesieniu do tekstu zamiennie. 
działem przestrzeni tekstowej odbiorcy ${ }^{3}$, ponieważ podczas lektury na podstawie wiedzy o świecie i sygnałów tekstowych - tworzy on bardzo szybko własne schematy makrostrukturalne i wydobywa $\mathrm{z}$ danego urywka istotne, $z$ jego punktu widzenia, makrosądy (por. R. S. Tomlin at al. 2001: 66).

\section{Eksponenty orientacji w tekście}

Eksponenty orientacji w tekście są oznaczane przez takie sygnały, które ułatwiają czytelnikowi orientację w przestrzeni tekstowej. Dzięki nim tworzymy własne schematy makrostrukturalne, co znacznie zwiększa naszą szansę na pomyślne odkrycie zamysłu autora. Za A. Duszak (1998: 128-172), dzielimy je na dwie grupy: strategiczne pozycje tekstowe i retoryczne podstawy orientacji w tekście.

\subsection{Strategiczne pozycje tekstowe}

Do grupy strategicznych pozycji tekstowych zaliczamy "sygnały, które jakoby organizują przestrzeń tekstową, wytyczają jej punkty strategiczne, a tym samym pomagają odbiorcy ustalić, $w$ jakim miejscu się znajduje i w jaką stronę powinien zmierzać, dążąc do całościowej interpretacji danego zdarzenia tekstowego" (A. Duszak 1998: 127). Autorka wymienia w pierwszym rzędzie tytuły oraz środki kontekstualizacji o podobnej funkcji, do których zalicza podtytuły, śródtytuły i nagłówki prasowe i stwierdza, że tytuł pełni funkcję makrostrukturalną, ponieważ "aktualizuje tekst, bo zakotwicza go w świecie relewantnym dla odbiorcy, a tym samym sygnalizuje potencjał makrostrukturalny tekstu (...)" (Ibidem, s. 129). W drugim rzędzie autorka wskazuje na wewnętrzne podziały przestrzeni tekstowej, segmentację, czyli podział struktury treści tekstu na odcinki (np. akapity). Pozycja otwarcia i zamknięcia tekstu lub segmentu tekstowego tworzy tzw. ramę tekstu (por.

\footnotetext{
3 Podziału na akapity niezależnie od decyzji autora dokonują również redaktorzy, zwłaszcza w przypadku tekstów naukowych, popularnonaukowych i publicystycznych.
} 
T. Dobrzyńska 1974, 1991, 1992, 1993; J. Labocha 1990: 80). „Na treściach zlokalizowanych w tych pozycjach skupia się zwiększona uwaga odbiorcy" (A. Duszak 1998: 128), co prowadzi do intensyfikacji procesów odbioru i przetwarzania informacji oraz stanowi istotny czynnik wspomagający orientację odbiorcy w przestrzeni tekstowej.

Podstawę delimitacji tekstu w ujęciu wielu badaczy stanowił akapit, ponieważ zauważono wyraźne związki pomiędzy przerwą w przestrzeni tekstowej a treścią i schematem gatunkowym tekstu (zob. E. V. Padučeva 1971; J. Grimes 1975; R. Longacre i S. Levisohn 1978; R. Longacre 1979; S. Gajda 1982; T. A. van Dijk i Kintsch 1983; R. de Beaugrande 1984). Wielu badaczy uważa, że względy znaczeniowe odgrywają istotną rolę w sposobie segmentacji tekstu i zasady delimitacji mają podstawę semantyczno-tematyczną, a ich celem jest zorientowanie czytelnika co do miejsca, w którym zachodzi zmiana tematu (por. J. Grimes 1975: 103; T. A. van Dijk 1980: 221; T .A. van Dijk i W. Kintsch 1983: 188; R. de Beaugrande 1984: 319 i in). Nie ma natomiast zgodności co do miejsca zmiany linii tematycznej $\mathrm{w}$ obrębie akapitu. W przekonaniu wielu naukowców zastosowanie segmentacji tekstu następowało przed wprowadzeniem nowego tematu (zob. W. Chafe 1979; A. J. Sanford i S. C. Garrod 1981). Natomiast R. Giora (1983) twierdzi, że pojawianie się podziału może następować zarówno przed, jak i po wprowadzeniu nowego tematu. Niezależnie od miejsca pojawiania się owych sygnałów, treści zawarte $w$ akapicie powinny dotyczyć jednego tematu. Są $w$ ten sposób przez nadawcę $w$ pewien sposób organizowane. Akapit może być zatem rozpatrywany jako funkcjonalna jednostka tekstu.

Akapit, w odróżnieniu od zdania, które może funkcjonować samodzielnie, tj. poza tekstem, jest bezsporną, unikalną i naturalną kategorią tekstową. Ułatwia czytelnikowi orientację $w$ strukturze globalnego planu treści. $Z$ jednej strony struktura akapitu zapewnia mu jedność, $\mathrm{z}$ drugiej strony - akapit spełnia funkcję integracyjną w stosunku do sąsiednich segmentów w przestrzeni tekstowej. Akapit jako kategoria tekstowa pod względem lokalizacji $\mathrm{w}$ tekście, swego rozmiaru oraz stopnia konceptualnego scalania, czy wreszcie przejrzystości organizacji hierarchicznej jest konstrukcją względną. Owa względność wynika $\mathrm{z}$ braku jednoznacznego pojmowania kategorii tekstowej i w pełni 
wypracowanych kryteriów oraz metod wyodrębniania segmentów tekstowych. Specyfika akapitu uzależniona jest od języka i od oczekiwań kompozycyjnych odbiorcy. Naturę akapitu „w sposób istotny określają czynniki typologiczne (genre), sytuacyjne i kulturowe" (A. Duszak 1998: 147).

Powstające w wyniku segmentacji struktury akapitowe odzwierciedlają zazwyczaj sytuację i intencje piszącego. Odbiorca natomiast odbiera tekst na swój indywidualny sposób, przypisując zdarzeniom komunikacyjnym, zgodnie $\mathrm{z}$ formułą koherencji kognitywnej ${ }^{4}$, informacje pozyskane zarówno $\mathrm{z}$ materiału tekstowego jak i z wiedzy ogólnej reprezentującej rzeczywistość pozajęzykową. Oznacza to, że segmentacja tekstu opierająca się na strukturach akapitowych spełnia zadanie wówczas, kiedy wspomaga orientację w tekście zgodnie z założeniem przyjętym przez nadawcę.

\subsubsection{Strategiczne pozycje tekstowe a segmentacja tekstu naukowego}

Strategiczne pozycje tekstowe, a wśród nich segmentacja tekstów naukowych, zależą $\mathrm{w}$ głównej mierze od pododmian stylu naukowego ${ }^{5}$. Biorąc pod uwagę właściwości procesu komunikacji naukowej, tzn. stopień abstrakcji treści i komunikujące się osoby, wśród pododmian stylu naukowego wyróżnia się pododmianę naukowo-specjalistyczną, dydaktyczno-naukową, popularnonaukową i użytkową, określaną w literaturze przedmiotu również jako praktyczną.

Ze względu na charakter komunikacji w danej dziedzinie zawodowej wyodrębnia się dwie grupy tekstów: a) teksty realizujące komunikację na płaszczyźnie teoretycznej (monografie, rozprawy naukowe,

4 A. Duszak interpretuje koherencje kognityzunq jako przypisywanie przez ludzi zdarzeniom komunikacyjnym cech na podstawie informacji, ,jaką pozyskują oni z formy zapisu tekstu oraz ze swojej wiedzy ogólnej, czerpanej ze znajomości rzeczywistości pozajęzykowej. Tekstowość staje się więc efektem aktu subiektywnej interpretacji i zależy zarówno od świadectw natury językowej, jak od sprawności intelektualnej czy też doświadczeń społecznych odbiorcy" (A. Duszak 1998: 126).

5 Ze względu na zróżnicowanie przedmiotowe i metodologiczne nauk można wyróżnić trzy pododmiany stylu naukowego: a) naukowo-przyrodniczy (chemia, biologia, medycyna), b) naukowo-humanistyczny (filologia, prawo, historia), c) naukowo-techniczny (dyscypliny techniczne, fizyka, matematyka) (por. M. Rachwałowa 1986: 19). Ow podział znajduje uzasadnienie w opiniach wielu naukowców, którzy twierdzą, że zróżnicowanie przedmiotowe i metodologiczne nauk oraz wynikające $\mathrm{z}$ tego podziały wpływają na wewnętrzną dyferencjację naukowej odmiany języka (zob. A. Furdal 1973; S. Gajda 1976, 1982, 1990a; J. Bartmiński 1981, 1991). 
artykuły, referaty, wykłady, recenzje, tezy referatów, streszczenia i abstrakty publikowane zamiast tekstu, podręczniki, opracowania, książki i poradniki o charakterze edukacyjnym, artykuły popularnonaukowe), b) teksty realizujące komunikację na płaszczyźnie praktycznej (na przykładzie medycyny: wyniki laboratoryjne, sprawozdania pooperacyjne, opinie lekarskie - obdukcje i ekspertyzy, diagnozy, karty chorych, recepty szczegółowe oraz teksty-instrukcje) (por. P. Lönning 1981: 82; Z. Kozłowska 1995: 21).

Najwyższy stopień rozczłonkowania poziomego (segmentacji) cechuje monografię, rozprawę naukową, referat i artykuł. Wykazują one czteroelementowy rozkład przestrzeni tekstowej: akapit - nadakapit - paragraf - tekst. Artykuł poprzedza zazwyczaj streszczenie (często dodatkowo w języku angielskim). Po nim umieszcza się słowa-klucze (również w tłumaczeniu na język angielski). Tekst właściwy składa się ze wstępu, opisu metody badawczej, przedstawienia wyników, dyskusji i wniosków. Owe segmenty bywają często zaopatrzone w śródtytuły i dzielą się na akapity. Wyniki badań ilustrują tabele, grafy, fotografie, zdjęcia rentgenowskie itp. Materiał ilustracyjny nie zawsze znajduje się w przestrzeni segmentu zawierającego jego opis. Bywa zamieszczany $\mathrm{w}$ innym miejscu płaszczyzny tekstowej, do którego kierują czytelnika odpowiednie odsyłacze. Artykuł naukowy kończy się zazwyczaj spisem literatury. Ten rejestr bywa nie dołączany, jeżeli w tekście pełne dane źródłowe wykazano w nawiasach lub klamrach. Zdarza się też, jak wykazały badania niemieckojęzycznych artykułów medycznych, że autor $\mathrm{z}$ jakichś powodów pomija w zupełności dane bibliograficzne, informuje natomiast Literatur: bei der Verfasserin - Literatura: $u$ autorki.

Artykuły popularnonaukowe charakteryzują się różnorodnym rozczłonkowaniem poziomym. Mogą przypominać artykuł naukowy, jednakże ze względu na możliwości percepcyjne odbiorcy-laika bywają $\mathrm{z}$ reguły zaopatrzone $\mathrm{w}$ silniej (re)orientujące sygnały mnemotechniczne, do których zaliczamy wyeksponowane nagłówki prasowe, fotografie poprzedzające tekst główny jak również liczne fotografie i ilustracje wbudowane w przestrzeń tekstową, które wraz z śródtytułami dzielą ją na poszczególne segmenty. Dodatkowe teksty zamieszczane na marginesach lub na tle fotografii bywają streszczeniem pewnych segmentów tekstowych lub zawierają uzupełniające informacje wzbogacające treść 
przekazu zasadniczego. Artykuły popularnonaukowe napisane w formie wywiadu charakteryzują się wstępem przedstawiającym osobę lekarza (naukowca), z którą przeprowadzono rozmowę, oraz strukturą wydzielaną pytaniem i odpowiedzią. Pytanie jest zazwyczaj zapisane pogrubioną czcionką.

Teksty - instrukcje cechuje wyraźna segmentacja podkreślana śródtytułami. Poszczególne człony tekstu mają za zadanie kierować działaniem adresata krok po kroku w obsłudze określonego urządzenia medycznego przeznaczonego do użytku w warunkach domowych, np.: ciśnieniomierza, inhalatora, elektronicznego termometru i itp., tak, aby jego zastosowanie nie wyrządziło szkody zdrowiu i nie naraziło producenta na wysokie koszty odszkodowania.

Typowym przykładem tekstu użytkowego jest instrukcja użycia leku. Składa się ona zazwyczaj z określonej liczby segmentów oznaczonych śródtytułami, na przykład: skład leku, opis działania, wskazania, przeciwwskazania, ostrzeżenia i środki ostrożności, interakcje, dawkowanie i sposób podawania (dzieci i dorośli), działania niepożądane, przechowywanie, dostępne opakowania, nazwa i adres wytwórcy jak również data opracowania lub data ostatniej weryfikacji ulotki. Liczba segmentów i ich tytułów zależy od rodzaju leku. Leki o skomplikowanym działaniu, dostępne wyłącznie na receptę (antybiotyki, leki psychotropowe, nasercowe, sterydowe $\mathrm{i}$ in.), zaopatrzone są zawsze $\mathrm{w}$ bardziej rozczłonkowaną instrukcję użycia. Dodatkowe segmenty wnoszą szczegółowe informacje na temat: stosowania $w$ ciąży lub podczas karmienia piersiq, wplywu na zdolność kierowania pojazdami mechanicznymi, obsługi maszyn i sprawności psychofizycznej, interakcji, sposobu postępowania po przedawkowaniu $i$ in. Zwiększenie pojemności informacyjnej wiąże się $z$ podwyższonym ryzykiem pogorszenia stanu zdrowia lub nawet zagrożenia życia w przypadku niewłaściwego zastosowania leku o silnym działaniu.

Analiza sposobu segmentacji medycznych tekstów naukowych oraz instrukcji użycia leków wykazuje wyraźnie skonwencjonalizowany charakter podziału przestrzeni tekstowej. Standardowy sposób segmentacji sprzyja fortunności odczytywania treści przekazu, co jest niezmiernie ważne w przypadku tekstów adresowanych do określonego odbiorcy. Natomiast teksty popularnonaukowe wykazują mniej ustabilizowany sposób rozczłonkowania, który wydaje się być zależny zarów- 
no od autora jak i redakcji. Redakcje medycznych czasopism popularnonaukowych dbają o skonwencjonalizowaną strukturę tekstu. Dowodem na to są, przykładowo, artykuły publikowane w magazynie "People" asygnowanym przez lekarzy Szpitala Klinicznego w Wiedniu, lub materiały informacyjne Technicznej Kasy Chorych w Niemczech (Techniker Krankenkasse). Natomiast czasopisma o charakterze ogólnym, w których znajdujemy rubryki poświęcone problemom zdrowotnym lub tylko pojedyncze artykuły, prezentują dużą swobodę w poziomym planie tekstów.

\subsection{Retoryczne podstawy orientacji $w$ tekście}

Tekst może być postrzegany w kategoriach interakcyjnych jako forma działania nastawiona na cel. Takie założenie pozwala na wyodrębnienie retorycznych podstaw orientacji w tekście. Wynikają one z intencji nadawcy i odzwierciedlają jego decyzje związane ze sposobem prezentacji i organizacji treści. Nadawca dąży do osiągnięcia określonego celu za pomocą komunikatu językowego. Zakodowanym w owym komunikacie znaczeniom można więc przypisać retoryczny charakter.

Adresat może odkrywać intencje nadawcy dzięki (meta)językowym wykładnikom funkcji retorycznych ${ }^{6}$. Interpretacja tekstu przebiega często poprzez stawianie pytań i poszukiwanie odpowiedzi. W dużym uogólnieniu można wyodrębnić dwa zasadnicze pytania: Co mówi autor? W jakim celu to mówi? Pytania i odpowiedzi można interpretować $\mathrm{w}$ kategoriach stawiania problemów i ich rozwiązywania. $\mathrm{W}$ tym ujęciu mówimy o problemowej strukturalizacji tekstu. Odkrywanie treści całego tekstu lub chociażby jego fragmentu zależy nie tylko od rodzaju pytań i odpowiedzi, lecz również od kolejności ich następowania (por. A. Duszak 1998: 160-164). Inaczej mówiąc, jakość wyborów owych pytań i odpowiedzi oraz ich kolejność będą stanowić

\footnotetext{
6 Zakres badań obejmujący tego typu sygnały jest bardzo szeroki, jednakże, zdaniem większości badaczy (np. T. A. van Dijk 1977; E. Winter 1977, 1994; M. Hoey 1983, 1994), owe sygnały ujawniają się poprzez leksykalne i składniowe wskaźniki orientujące odbiorcę w strukturze celów nadawcy.
} 
o stopniu zrozumienia komunikatu. Według J. Grimesa (1975: 211), każdy tekst można zinterpretować, wskazując na zawarty w nim problem, który adresat usiłuje zanalizować, ocenić i rozwiązać. Analizując tekst $\mathrm{z}$ punktu widzenia związków zachodzących między podziałami w przestrzeni tekstowej, można wyróżnić segmenty o charakterze makrostrukturalnym reprezentujące tekstowe znaczenia globalne. „Dla określenia tych struktur używa się także terminów: temat globalny tekstu, temat dyskursu (discourse topic), a także sedno (gist), kwintesencja tekstu (essence) lub streszczenie (summary)" (A. Duszak 1998: 188). Temat globalny jest więc główną treścią przekazu - celem, dla którego tekst został napisany. Wskazanie segmentu makrostrukturalnego ma więc zasadnicze znaczenie $\mathrm{w}$ procesie scalania wiedzy podczas lektury tekstu. Ten segment zawiera ukierunkowanie na najważniejsze informacje, lub wręcz, same informacje. W artykułach naukowych funkcję segmentów makrostrukturalnych pełnią zazwyczaj streszczenia lub wstępy.

Strategiczne pozycje tekstowe są graficznie uzewnętrznionym sposobem segmentacji tekstu, co oznacza, że adresat z łatwością je dostrzeże, nie wnikając w sens komunikatu. Wydzielone części nie muszą się jednak pokrywać z problemowym charakterem struktury tekstu.

Jako przykład mogą posłużyć fragmenty dwóch różnych tekstów-instrukcji użycia leku asygnowanych przez firmę BAYER. Pierwszy z nich dotyczy aspiryny o nazwie ASPIRIN plus C, drugi - ASPIRIN 325. Fragmenty przedstawiają zbliżone treści, jednakże sposób segmentacji płaszczyzny tekstowej wykazuje znaczne różnice.

\section{Tekst nr 1}

Przeciwwskazania: ASPIRIN plus C nie wolno stosować przy patologicznie podwyższonej skłonności do krwawień.

ASPIRIN plus C można przyjmować po uprzednim zasięgnięciu porady lekarskiej w następujących przypadkach: jednoczesne leczenie środkami przeciwkrzepliwymi (np. pochodnymi kumaryny, heparyna), niedobór dehydrogenazy glukozo-6-fosforanu, astma lub nadwrażliwość na salicylaty, leki przeciwzapalne / przeciwreumatyczne oraz inne substancje uczulająe, przewlekłe i nawracajace dolegliwości żoładkowe, w tym choroba wrzodowa żoładka i dwunastnicy, uszkodzenie nerek, ciq̨ża - zwłaszcza w ostatnich trzech miesiącach. 
Uwaga: Chorzy cierpiacy na astmę, katar sienny, obrzęk błony śluzowej nosa (polipy nosa) lub przewlekte zakażenia dróg oddechowych (zwłaszcza spowodowane katarem siennym) oraz chorzy $z$ nadwrażliwościq na różnego rodzaju środki przeciwbólowe i przeciwreumatyczne narażeni sq na niebezpieczeństwo wystapienia ataków astmy (tzw. nietolerancji środków przeciwbólowych powodujacych astmę wywołanq środkami przeciwbólowymi). Ci pacjenci powinni przed zastosowaniem leku zasięgnać porady lekarza. Dotyczy to także chorych, u których występuje alergia objawiająca się zmianami skórnymi, świq̨em lub pokrzywką.

W przypadku stwierdzenia cią̇̇y podczas dłuższego stosowania ASPIRIN plus C należy skontaktować się z lekarzem, a przy dłuższym stosowaniu wysokich dawek leku w okresie karmienia piersiq należy rozważyć wcześniejsze przerwanie kuracji.

ASPIRIN plus $C$, w wypadku chorób objawiających się u dzieci i młodzieży goraczka, powinna być stosowana na zlecenie lekarza, oraz wówczas, gdy inne środki nie sq skuteczne.

Jeżeli w trakcie choroby występuja zbyt długo utrzymujace się wymioty, należy wziąć pod uwagę zespót Reye.

Jest to bardzo rzadkie i zagrażajace życiu schorzenie wymagajace bezwarunkowo natychmiastowej pomocy lekarskiej.

Tekst nr 2

\section{Przeciwwskazania}

Preparatu nie można stosować:

- $w$ przypadku nadwrażliwości na substancję czynnq - kwas acetylosalicylowy, inne salicylany lub którykolwiek składnik leku (patrz: Ostrzeżenia),

- u pacjentów ze skazq krwotoczna,

- $w$ chorobie wrzodowej żoładka lub dwunastnicy,

- $w$ ostatnim trymestrze ciaży,

- przy grypie i ospie wietrznej u dzieci do 12 lat.

\section{Ostrzézenia}

Preparat może być zastosowany tylko po ścistym rozważeniu stosunku ryzyka do korzyści w następujących przypadkach:

- pierwszy i drugi trymestr ciaży,

- okres karmienia piersia, 
- nadwrażliwość na niesteroidowe leki przeciwzapalne lub inne substancje alergizujące,

- podczas jednoczesnego leczenia środkami przeciwzakrzepowymi (np. pochodnymi kumaryny lub heparyny),

- u pacjentów ze znacznq niewydolnościq wątroby i nerek,

- u pacjentów z chorobq wrzodowq,

- u pacjentów z niedoborem dehydrogenazy glukozo-6-fosforanowej.

W związku z możliwościa wystapienia zespołu Reye'a - rzadkiej, ale ciężkiej choroby - lek można zastosować w celu obniżenia gorączki u dzieci i młodzieży poniżej 12 lat wyłącznie na zlecenie lekarza.

Pacjenci z astma oskrzelowa, przewlektymi chorobami układu oddechowego, goraczkq siennq lub obrzękiem błony śluzowej nosa (polipy nosa) mogq reagować częściej niż inni na niesteroidowe leki przeciwzapalne atakami astmy, ograniczonym obrzękiem skóry i błony śluzowej (obrzęk naczynioruchowy) lub pokrzywką.

\section{Stosowanie leku podczas ciqży i karmienia piersiq}

Kwas acetylosalicylowy może być stosowany w 1 i 2 trymestrze ciaży tylko po warunkiem ścisłego rozważenia stosunku ryzyka do korzyści i wyłącznie na zlecenie lekarza.

Preparatu nie należy stosować w ostatnim trymestrze cią̇y, gdyż może powodować wady płodu i komplikacje w czasie porodu.

Kwas acetylosalicylowy przenika $w$ niewielkich ilościach do mleka matki, dlatego - jeżeli to możliwe - należy unikać stosowania preparatu $w$ czasie karmienia piersia.

Przeciwwskazania są, jak wiadomo, zbiorem zakazów wyłączających stosowanie leku w przypadku wymienionych w instrukcji dolegliwości. Ostrzeżenia natomiast zawierają informację o możliwości ograniczonego stosowania leku z uwzględnieniem potencjalnego ryzyka. Stosowanie leku podczas ciąży i karmienia piersia stanowi konkretyzację adresata i informuje o niestandardowym, ograniczonym użyciu preparatu. Ten segment łączy zazwyczaj ostrzeżenia $z$ przeciwwskazaniami, jak to ilustruje tekst nr 2, z którego dowiadujemy się, że w pierwszym i drugim trymestrze ciąży dopuszcza się stosowanie Aspirin plus $C$, jeżeli lekarz na to zezwoli. Zdanie zawierające tę informacje jest ostrzeżeniem przed ewentualnym negatywnym wpływem leku 
na zdrowie matki i dziecka. Następne zdanie jest wyraźnym przeciwwskazaniem użycia leku w ostatnim trymestrze ciąży. Aby unaocznić niebezpieczeństwo wynikające ze zlekceważenia tego zakazu, dowiadujemy się o możliwości wystąpienia wad płodu i komplikacji w czasie porodu.

W tekście nr 1 wyodrębniono informacje odnośnie stosowania leku w czasie ciąży i karmienia przy pomocy akapitu, nie poprzedzając go śródtytułem. Ten fragment można więc potraktować jako integralną część uwag, co w tym wypadku znajduje nawet uzasadnienie, ponieważ nie wyklucza się użycia preparatu w określonych etapach ciąży i karmienia piersią, jak w tekście nr 2.

Reasumując stwierdzamy, że w pierwszym fragmencie wszystkie informacje znalazły się pod jednym śródtytułem - Przeciwwskazania. Ostrzeżenia zostały wyodrębnione $\mathrm{w}$ nowym akapicie poprzedzonym słowem - Uwaga, które można uznać za synonim - Ostrzeżenia. Drugi przykład tekstu obrazuje szczegółową konkretyzację ostrzeżeń i podkreśla ją odrębnymi śródtytułami. Oprócz akapitu i śródtytułu, orientującą funkcję w przestrzeni tekstowej spełnia wypunktowanie istotnych informacji.

Pytanie, który z przytoczonych tekstów przemówi do odbiorcy trafniej dzięki zastosowanej w nim segmentacji, jak również innych eksponentów orientujących w planie treści, pozostaje otwarte i należy do grupy wciąż aktualnych problemów tekstologii jako zagadnienie dotyczące kryterium delimitacji tekstu $\mathrm{w}$ aspekcie funk $\mathrm{k}_{\mathrm{c} j o n a l n o-k o m u n i k a-}$ tywnym.

Wieloaspektowość zjawisk tekstowych wymusza więc konieczność analizy poszczególnych elementów struktury tekstu rozumianego jako konstrukcji podlegającej delimitacji. Delimitacja dotyczy w tym ujęciu struktur głębokich i jest podziałem dyskretnym. Struktury głębokie oznaczają całokształt środków językowych pełniących swoją rolę w granicach danego tekstu i biorących udział w jego strukturacji jako całości. W przeciwieństwie do struktur powierzchniowych, struktura głęboka nie jest dostępna bezpośredniej obserwacji (por. S. Urbańczak (red.) 1994: 338). Jej istnienie wykrywamy na podstawie wnikliwej analizy językoznawczej. 


\section{Bibliografia}

Bartmiński J. [1981], Derywacja stylu, [w:] Pojęcie derywacji w lingwistyce, red. J. Bartmiński, Lublin, s. 31-54.

Bartmiński J. [1991], Styl potoczny jako centrum systemu stylowego jezyka, [w:] Synteza w stylistyce stowiańskiej. Materiały konferencji $z$ 26.09.1990 w Opolu, Opole, s. 33-47.

Beaugrande R. [1984], Text Production, NJ: Ablex, Norwood.

Beaugrande R., Dressler W. [1990], Wstęp do lingwistyki tekstu, tłum. A. Szwedek, PWN, Warszawa.

Chafe W. L. [1979], The flow of thought and the flow of language, [w:] Discourse and Syntax. Syntax and Sematics 12, red. T. Givon, Academic Press, New York, s. 159-181.

Dąbrowska E. [1995], Styl artystyczny, [w:] Przewodnik po stylistyce polskiej, red. S. Gajda, Opole, s. 219-362.

van Dijk T. A. [1977], Text and Context, London.

van Dijk T. A. [1980], Macrostructures, NJ: Lawrence Erlbaum Associates, Hillsdale.

van Dijk T. A., Kintsch W. [1983], Strategies of Discourse Comprehension, Academic Press, New York.

Dobrzyńska T. [1974], Delimitacja tekstu literackiego, Ossolineum, Wrocław.

Dobrzyńska T. [1991], Przekład wyrażeń metaforycznych (Problemy znaczeniowe), [w:] Synteza $w$ stylistyce słowiańskiej, red. S. Gajda, WSP, Opole, s. 107-115.

Dobrzyńska T. (red.) [1992], Typy tekstów. Zbiór studiów, Wydawnictwo IBL PAN, Warszawa.

Dobrzyńska T. [1993], Tekst. Próba syntezy, IBL, Warszawa.

Duszak A. [1998], Tekst dyskurs, komunikacja międzykulturowa, PWN, Warszawa.

Furdal A. [1973], Klasyfikacja odmian współczesnego języka polskiego, Wrocław.

Giora R. [1983], Functional paragraph perspective, [w:] Micro and Macro.

Grimes J. [1975], The Thread of Discourse, Mounton, The Hague.

Gajda S. [1982], Podstawy badań stylistycznych nad językiem naukowym, PWN, Warszawa. 
Gajda S. [1976], Rozwój polskiej terminologii górniczej, Opole. Gajda S. [1990a], Wprowadzenie do teorii terminu, WSP, Opole.

Hoey M. [1983], On the surface of discourse, George Allen \& Unwin, London.

Hoey M. [1994], Signalling in discourse: a functional analysis of a common discourse pattern in written and spoken English, [w:] Advances in Written Text Analysis, red. M. Coulthard, London, s. 26-45.

Labocha J. [1990], Opowiadania ludowe ze Ślaska Cieszyńskiego w Czechosłowacji w świetle pragmalingwistyki tekstu, Kraków.

Longacre R. [1979], The paragraph as a grammatical unit, [w:] Discourse and Syntax. Syntax and Sematics 12, red. T. Givon, Academic Press, New York, s. 115-134.

Longacre R., Levisohn [1978], Field analysis of discourse, [w:] Current Trends in Textlinguistics, red. W. Dressler, Berlin, s. 103-122.

Lönning P. [1981], Zur medizinischen Fachsprache, „Muttersprache”, Wiesbaden, nr 91, s. 79-92.

Łotman J. [1984], Struktura tekstu artystycznego, PAN, Warszawa.

Mathesius V. [1971], Untersuchungen zu terminologischen Wortverbindungen der Fachsprachen, „Wissenschaftliche Zeitschrift der TU Dresden", nr 5, s. 56-64.

Kozłowska Z. [1995], O przekładzie tekstu naukowego (na materiale tekstów językoznawczych), wyd. UW, Warszawa.

Padučeva E. V. [1971], O strukturze akapitu, [w:] O spójności tekstu, red. M. Mayenowa, Ossolineum, Wrocław, s. 95-103.

Rachwałowa M. [1986], Słownictwo tekstów naukowych, Ossolineum, Wrocław.

Strunk W., White E. [1979], The Elements of Style, Macmillan Publishers, New York.

Tomlin R. S., Forrest L., Pu M. M., Kim M. H. [2001], Semantyka dyskursu, [w:] T. A. van Dijk, (red.), s. 45-101.

Winter E. [1977], A clause relational approach to English texts: a study of some predictive lexical items in written discourse, "Instruktional Science", nr 6, s. 1-92.

Winter E. [1994], Clause relational as information structure: two basic text structures in English, [w:] Advances in Written Text Analysis, red. M. Coulthard, London, s. 46-68. 


\section{SCIENTIFIC TEXT SEGMENTATION}

\section{Summary}

Problems concerning the division of textual space in scientific literature, in particular medical sublanguage, are discussed in the present paper. Both pragmatic signals of segmentation facilitating prognosis of content continuity and functional-communicative signals including language exponents were analyzed.

The paper is an attempt to answer the following questions: when is communication the best?; what are the conditions ensuring communicative efficiency of a text)?; what should be a text like to arouse interest in the addressee?; what is the secret of aesthetic influence of a text?, etc.

Major conditions of the most effective harmonious dialogue between the author and the addressee are mentioned as follows: 1) presence of contact, 2) knowledge of code (language), 3) common thesaurus (knowledge of the world), 4) partnership of communication participants, 5) presence of appropriate intentions (aims, motives), 6) presence of communication and pragmatic principles of communications. 